\title{
UJI TOKSISITAS DAN IDENTIFIKASI FITOKIMIA EKSTRAK BUAH DAN BATANG RIMBANG (Solanum torvum Swartz)
}

\section{TOXICITY TEST AND PHYTOCHEMICAL IDENTIFICATION OF RIMBANG (Solanum torvum Swartz) EXTRACT}

\author{
Muhammad Alfarabi*, Gupita Widyadhari \\ Departemen Biokimia, Fakultas Kedokteran, Universitas Kristen Indonesia, Jakarta, Indonesia. \\ *Corresponding author: muhammad.alfarabi@uki.ac.id
}

Naskah Diterima: 24 Juli 2017; Direvisi: 27 Februari 2018; Disetujui: 16 Maret 2018

\begin{abstract}
Abstrak
Indonesia memiliki banyak tumbuhan yang dapat digunakan sebagai sumber pangan dan obat, salah satunya adalah rimbang (Solanum torvum Swartz). Rimbang telah dikenal luas sebagai sayuran yang buahnya dapat dimakan secara mentah dan dapat digunakan dalam pengobatan tradisional. Namun demikian, tidak banyak kajian ilmiah mengenai efek toksik beserta senyawa yang terkandung pada buah dan batang rimbang, sehingga tujuan dari penelitian ini adalah memberikan informasi efek toksisitas dari ekstrak buah dan batang rimbang serta senyawa yang terkandung di dalamnya. Metode yang digunakan untuk menguji toksisitas adalah Brine Shrimp Lethality Test (BSLT) dan deteksi senyawa menggunakan uji fitokimia. Hasil penelitian menunjukkan bahwa ekstrak buah dan batang rimbang memiliki efek toksisitas. Nilai $\mathrm{LC}_{50}$ ekstrak buah rimbang sebesar 248 ppm, sedangkan nilai $\mathrm{LC}_{50}$ ekstrak batang rimbang sebesar 129 ppm. Ekstrak buah rimbang mengandung senyawa alkaloid dan tanin, sedangkan hasil uji fitokimia terhadap batang rimbang mengandung alkaloid, saponin, dan tanin. Kedua ekstrak tersebut memiliki potensi untuk dikembangkan menjadi salah satu sumber fitofarmaka antikanker.
\end{abstract}

Kata kunci: Fitokimia; Rimbang; Solanum torvum; Toksisitas

\begin{abstract}
Many plants in Indonesia are used as food and medicine, such as rimbang (Solanum torvum Swartz). This plant has been widely known as a vegetable which the fruit consumed in raw and also useful in traditional medicine. However, scientific studies on the toxic effects and compounds contained in its fruit and stem have not been widely carried out, so the aim of this study is to provide information on the toxicity effects of them and their compounds. The Brine Shrimp Lethality Test (BSLT) was used to determine the toxicity effect of the extracts, while the compounds in these extracts were detected by using phytochemical assay. The results showed that those extracts have toxicity effects. The $L C_{50}$ of the fruit extract was 248 ppm while the stem extract was 129 ppm. The fruit extract contained alkaloid and tannin, while the stem extract contained alkaloid, saponin, and tannin. Both extracts have potential to be a resource of anticancer phytopharmaca.
\end{abstract}

Keywords: Phytochemical; Rimbang; Solanum torvum; Toxicity

\section{Permalink/DOI: http://dx.doi.org/10.15408/kaunivah.v11i2.6360}




\section{PENDAHULUAN}

Indonesia merupakan negara di wilayah Asia Tenggara yang memiliki diversitas flora yang tinggi. Tumbuhan tersebut digunakan oleh masyarakat sebagai sumber pangan dan pengobatan tradisional. Sebagian kecil dari tumbuhan itu telah dibudidayakan karena memiliki nilai ekonomi yang tinggi dan merupakan sumber sayuran sehari-hari, diantaranya rimbang (Solanum torvum Swartz). Buah dari tanaman tersebut dapat dikonsumsi mentah. Tanaman ini memiliki nama yang berbeda-beda pada setiap daerah, seperti rimbang (Sumatera Barat dan Melayu), takokak (Jawa Barat), dan terong cepoka (Jawa Tengah). Tanaman tersebut telah dimanfaatkan sebagai obat tradisional pada masyarakat terutama di daerah Sumatera Barat karena digunakan sebagai obat mata (Sirait, 2009), oleh karenanya, tanaman ini dapat mendukung gaya hidup masyarakat sekarang yang ingin mengkonsumsi obat berbahan alami.

Rimbang merupakan spesies yang penting di bidang farmakologi karena telah banyak digunakan pada pengobatan tradisional Cina dan Ayurveda serta di beberapa negara Asia lainnya. Secara empiris, bagian daunnya dapat dikeringkan dan dibuat menjadi serbuk dan dicampurkan dengan air panas untuk mengobati batuk atau flu, akarnya dapat dijadikan serbuk untuk meringankan sakit pada patah kaki, buahnya yang dikeringkan dapat menjadi pereda batuk, ekstrak daunnya dapat digunakan untuk meredakan demam, serta ekstrak akarnya dapat digunakan untuk pengobatan asma dan penyakit liver (Yousaf et al., 2013). Secara ilmiah, ekstrak metanol dari buah rimbang memiliki efek toksik terhadap larva udang yang diuji dengan metode Brine Shrimp Lethality Test (BSLT) (Silva et al., 2007) dan ekstrak buah serta daun rimbang memiliki aktivitas antioksidan berdasarkan metode DPPH (2,2-diphenyl-1-picrylhydrazyl) (Loganayaki et al., 2010). Ekstrak etanol daun $S$. torvum yang tumbuh di wilayah Tidore, Maluku Utara juga memiliki aktivitas antioksidan dan efek toksik dengan metode BSLT. Kedua bioaktivitas tersebut menunjukkan bahwa ekstrak buah rimbang memiliki potensi untuk dikembangkan menjadi salah satu sumber fitofarmaka antikanker. Hal tersebut dikarenakan salah satu mekanisme penyebab terjadinya kanker adalah terjadinya akumulasi senyawa radikal bebas pada tubuh (Ahmadinejad et al., 2017) dan aktivitas antibakteri menunjukkan bahwa ekstrak tersebut memiliki efek toksik.

Informasi ilmiah mengenai efek toksik dari buah rimbang terutama ekstrak air dari buah tersebut hingga saat ini belum banyak dikaji secara ilmiah. Buah rimbang banyak dikonsumsi masyarakat secara mentah sehingga cara ekstraksi yang mendekati perlakuan yang terjadi di masyarakat adalah menggunakan ekstrak air. Batang dari rimbang hingga saat ini belum banyak dilakukan kajian ilmiahnya sehingga potensi batang tersebut di bidang kesehatan hanya sedikit diketahui, sehingga tujuan dari penelitian ini adalah untuk mengetahui efek toksisitas dari ekstrak buah rimbang dan batang rimbang.

\section{MATERIAL DAN METODE}

Bahan utama yang digunakan pada penelitian ini adalah buah dan batang rimbang segar yang didapatkan dari daerah Solok, Sumatera Barat, Indonesia. Buah yang digunakan adalah buah berwarna hijau yang siap dipanen untuk konsumsi sehari-hari dan batang yang digunakan adalah batang yang letaknya dekat dengan buah.

\section{Ekstraksi Buah dan Batang Rimbang}

Sebanyak $126 \mathrm{~g}$ buah dan batang rimbang dibersihkan, lalu diekstraksi menggunakan pelarut aquades steril. Perbandingan antara bahan ekstraksi dan pelarut adalah 1:2 (b/v), lalu dihomogenasikan serta disaring. Ekstrak yang didapat dijadikan larutan stok dengan konsentrasi 5000 ppm, lalu disimpan pada freezer dengan temperatur $-10{ }^{\circ} \mathrm{C}$ sampai siap diujikan.

\section{Uji Toksisitas dengan Metode Brine Shrimp Lethality Test (BSLT)}

Uji ini mengacu pada metode Meyer et al. (1982) dengan beberapa modifikasi. Larva udang yang digunakan adalah Artemia sp. berumur 48 jam sejak menetas dengan media air garam $(20 \mathrm{~g}$ garam di dalam $800 \mathrm{~mL}$ akuades steril). Ekstrak dengan beberapa konsentrasi (150 ppm, 200 ppm, 300 ppm, dan $400 \mathrm{ppm}$ ) dicampur dengan larva pada tabung uji (10 larva pada setiap tabung uji) dan uji dilakukan 3 ulangan. Volume total dari setiap 
tabung uji adalah $10 \mathrm{~mL}$. Campuran tersebut diinkubasi selama 24 jam pada temperatur ruang dengan penyinaran cahaya. Larva udang yang mati diamati dan dianalisis nilai $\mathrm{LC}_{50}$.

\section{Uji Fitokimia}

Prosedur identifikasi fitokimia ini mengacu pada metode Harborne (1987) dengan beberapa modifikasi. Uji yang dilakukan adalah sebagai berikut.

Sebanyak $2 \mathrm{~mL}$ ekstrak dicampur dengan $2 \mathrm{~mL}$ kloroform dan 5 tetes amonia pekat. Fraksi kloroform ditambahkan $\mathrm{H}_{2} \mathrm{SO}_{4}$ pekat sebanyak 3 tetes. Selanjutnya, campuran tersebut diteteskan pereaksi Dragendorf. Bahan uji dinyatakan memiliki senyawa alkaloid, apabila setelah diteteskan pereaksi Dragendorf memperlihatkan adanya warna merah.

Sebanyak $2 \mathrm{~mL}$ ekstrak dicampur akuades dan dipanaskan. Setelah itu larutan didinginkan dan disaring, filtrat yang didapat diteteskan $\mathrm{FeCl}_{3}$ 1\%. Larutan yang berubah warna menjadi biru tua atau hijau kehitaman menunjukan adanya tanin.

Ekstrak sebanyak $2 \mathrm{~mL}$ ditambahkan 2 $\mathrm{mL}$ akuades dan dipanaskan pada suhu $70{ }^{\circ} \mathrm{C}$. Setelah itu dikocok selama 5 menit. Bahan uji yang mengandung saponin akan menunjukkan adanya buih setelah dilakukan proses pemanasan dan pengocokan selama 10 menit.

\section{HASIL}

\section{Uji Toksisitas Ekstrak}

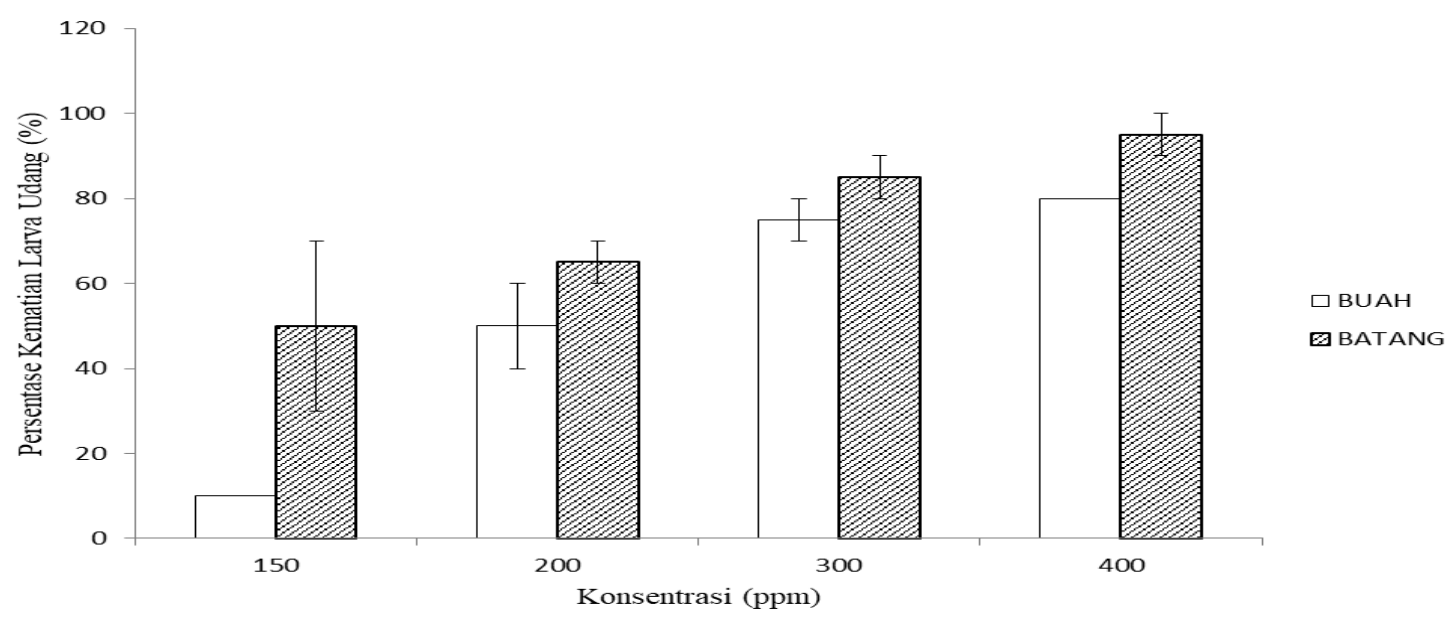

Gambar 1. Kematian larva udang terhadap konsentrasi ekstrak buah dan batang rimbang

\section{Uji Fitokimia}

Berdasarkan hasil uji fitokimia menunjukkan bahwa buah rimbang mengandung senyawa alkaloid dan tanin. Hasil
Ekstrak buah dan batang rimbang pada setiap konsentrasi memiliki efek toksik terhadap larva udang. Persentasi kematian larva udang tertinggi terjadi pada buah rimbang pada konsentrasi ekstrak 400 ppm yaitu sebesar $80 \%$ larva udang, sedangkan kematian larva udang terendah pada konsentrasi ekstrak 150 ppm yang hanya dapat mematikan 10\%. Presentasi kematian larva udang tertinggi pada batang rimbang pada konsentrasi ekstrak 400 ppm yang dapat mematikan $95 \%$ larva udang, sedangkan kematian larva udang terendah pada konsentrasi ekstrak $150 \mathrm{ppm}$ yang dapat mematikan 50\% (Gambar 1). Hasil uji menunjukkan, bahwa semakin tingginya kosentrasi ekstrak buah dan batang rimbang yang diberikan maka semakin tinggi angka kematian larva udang. Nilai $\mathrm{LC}_{50}$ yang didapatkan dari ekstrak buah rimbang sebesar 248 ppm, sedangkan nilai LC L0 $_{50}$ ekstrak batang rimbang sebesar 129 ppm. Daya toksik dari ekstrak buah dan batang rimbang berbeda, hal ini dapat dilihat dari perbedaan persentase kematian larva udang pada konsentrasi ekstrak tertinggi dan terendah serta nilai $\mathrm{LC}_{50}$. Ekstrak batang memiliki selang persentase kematian larva udang dari 50-95\%, sedangkan ekstrak buah memiliki selang $10-80 \%$. Nilai LC $_{50}$ ekstrak buah lebih besar dibandingkan dengan nilai $\mathrm{LC}_{50}$ ekstrak batang, sehingga daya toksik ekstrak batang lebih tinggi daripada ekstrak buah. 
Tabel 1. Hasil uji fitokimia buah dan batang rimbang

\begin{tabular}{|c|c|c|}
\hline Uji fitokimia & Buah rimbang & Batang rimbang \\
\hline Alkaloid & + & + \\
\hline Saponin & - & + \\
\hline Tanin & + & + \\
\hline
\end{tabular}

Keterangan: (+) Terdeteksi

(-) Tidak terdeteksi

\section{PEMBAHASAN}

Ekstraksi pada penelitian ini menggunakan akuades setelah buah dan batang rimbang dihaluskan. Hal ini dilakukan karena buah rimbang telah dikenal oleh masyarakat sebagai salah satu sumber pangan dan pada umumnya dikonsumsi mentah sehingga kondisi buah masih segar (Gambar 2). Ekstraksi adalah suatu proses untuk menarik senyawa fitokimia pada tumbuhan. Proses tersebut dapat dipengaruhi oleh sifat kimia dari senyawa tersebut dan tujuan dilakukannya ekstraksi (Harborne, 1987). Metode ekstraksi yang tepat untuk buah dan batang rimbang dan menyerupai cara konsumsinya pada masyarakat adalah ekstraksi menggunakan pelarut akuades. Secara tradisional di masyarakat, teknik rebusan adalah cara ekstraksi yang umum dilakukan untuk mengolah tanaman obat (Alfarabi \& Fauziayuningtias, 2017). Teknik tersebut terdapat kekurangan bila dibandingkan melakukan ekstraksi menggunakan pelarut kimia organik, yaitu senyawa yang terekstrak lebih banyak senyawa bersifat polar sesuai dengan polaritas air sebagai pelarut dan senyawa yang tidak tahan panas akan rusak dikarenakan proses merebus biasanya dilakukan pada temperatur $100{ }^{\circ} \mathrm{C}$.

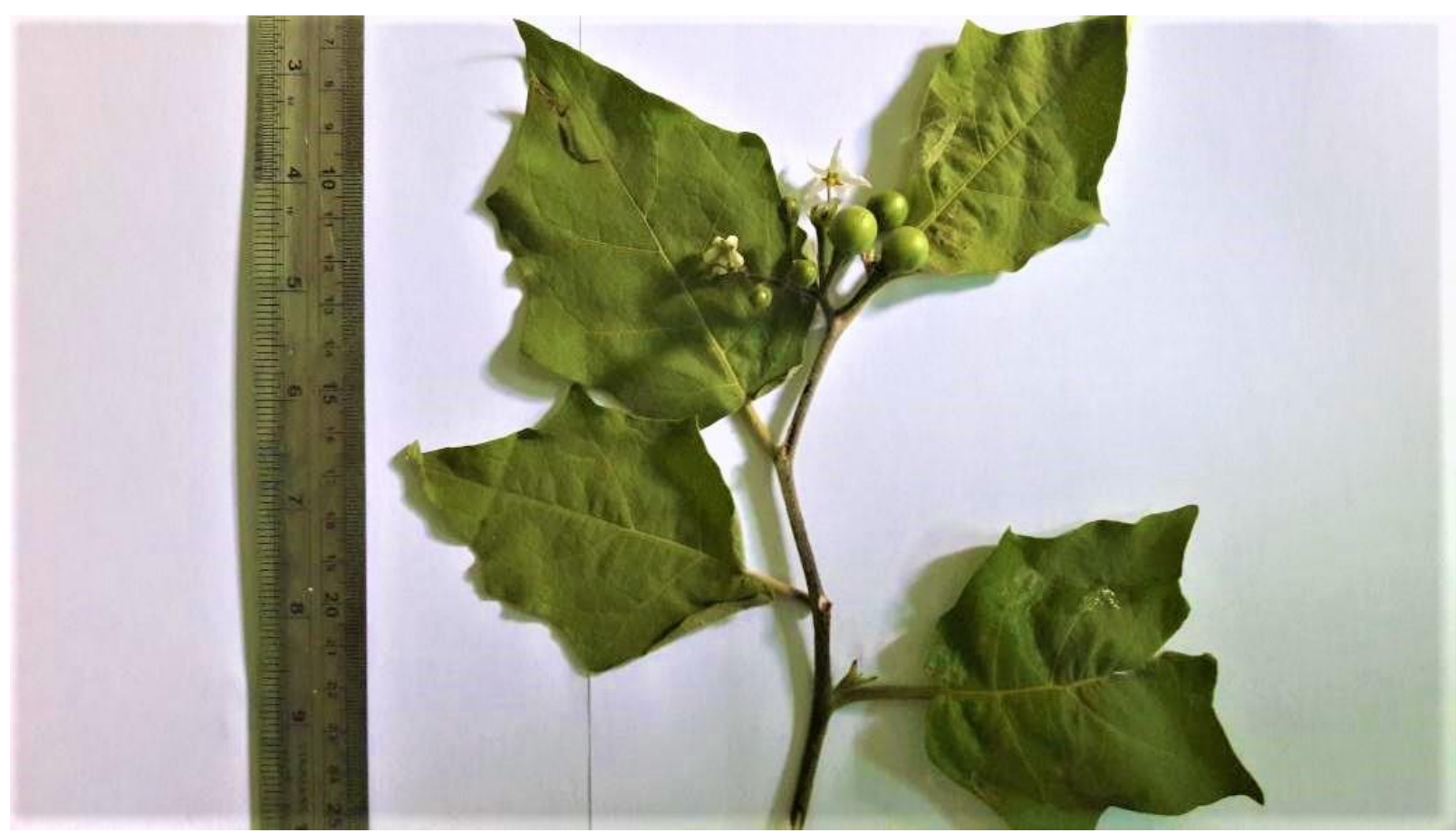

Gambar 2. Morfologi batang dan buah rimbang yang digunakan pada penelitian

Senyawa fitokimia yang telah terekstrak harus memiliki bioaktivitas sehingga dapat dikembangkan menjadi sumber fitofarmaka. Pengujian bioaktivitas dapat dilakukan dengan berbagai metode, salah satunya adalah BSLT. Uji ini dapat dikatakan merupakan uji tahap pertama karena dapat dilakukan dengan cepat untuk melihat aktivitas dari suatu senyawa serta efek toksiknya di dalam suatu ekstrak (Alfarabi et al., 2015). Prinsip dari uji ini adalah mengetahui efek toksik ekstrak terhadap larva udang. Senyawa fitokimia yang dicampurkan dengan larva udang akan mengganggu kehidupan dari larva tersebut bila tertelan sehingga larva akan mati. Efek toksik tersebut diasumsikan sebagai aktivitas dari 
senyawa yang terkandung di ekstrak tersebut. Senyawa pada ekstrak tumbuhan dapat dikatakan memiliki bioaktivitas atau memiliki efek toksik bila memiliki nilai $\mathrm{LC}_{50}$ di bawah 1000 ppm sedangkan bila di atas 1000 ppm dapat dikatakan tidak terdapat aktivitas atau tidak memiliki efek toksik (Meyer et al., 1982). Nilai $\mathrm{LC}_{50}$ adalah nilai dari konsentrasi suatu senyawa yang dapat menyebabkan kematian bahan uji sebanyak $50 \%$.

Nilai $\mathrm{LC}_{50}$ ekstrak buah dan batang rimbang pada penelitian ini di bawah 1000 ppm sehingga kedua ekstrak tersebut dapat dikatakan memiliki bioaktivitas. Nilai LC $_{50}$ yang berbeda antara ekstrak buah dan batang menunjukkan daya toksik yang berbeda, semakin rendah nilai $\mathrm{LC}_{50}$ dari suatu ekstrak menunjukkan bahwa daya toksik semakin tinggi. Hal ini karena dengan penggunaan konsentrasi senyawa yang rendah sudah dapat mematikan sebanyak 50\% jumlah larva udang. Hasil penelitian ini menunjukkan daya toksik ekstrak batang lebih tinggi daripada ekstrak buah. Perbedaan tersebut dapat terjadi karena senyawa yang terkandung pada batang dan buah berbeda. Setiap organ pada tumbuhan memiliki fungsi yang berbeda sehingga senyawa yang terkandung dapat juga berbeda. Buah pada tumbuhan merupakan salah satu organ yang berfungsi sebagai tempat penyimpanan cadangan metabolit karbohidrat sehingga dapat dikonsumsi oleh manusia, sedangkan batang merupakan organ yang mempunyai fungsi struktural atau penopang untuk tumbuhan tersebut sehingga tidak umum dikonsumsi (Taiz \& Zeiger, 2002). Selain buah dan batang, daun rimbang memiliki efek toksik dengan pengujian toksisitas metode BSLT. Nilai $\mathrm{LC}_{50}$ ekstrak etanol daun rimbang yang tumbuh di wilayah Tidore sebesar 113,762 ppm (Julfitriyani et al., 2016). Nilai LC 50 dari ekstrak buah dan batang rimbang pada penelitian ini memiliki efek toksik yang lebih rendah dibandingkan dengan ekstrak etanol daun rimbang. Hal ini disebabkan pelarut ekstraksi dan bahan uji yang berbeda. Etanol memiliki sifat yang lebih nonpolar daripada akuades dan merupakan salah satu pelarut yang baik untuk digunakan dalam proses ekstraksi (Harborne, 1987). Etanol dapat mengekstrak senyawa-senyawa fitokimia nonpolar lebih banyak dibandingkan akuades. Etanol pun dapat mengekstrak senyawa yang polar, sehingga senyawa yang terekstrak dengan penggunaan pelarut etanol lebih banyak dibandingkan dengan akuades. Daun merupakan organ pada tumbuhan yang utama dalam melakukan proses metabolisme sehingga biosintesis metabolit sekunder banyak terjadi di daun dibandingkan dengan batang dan buah (Heldt, 2011). Kedua hal tersebut yang dapat menjadikan ekstrak etanol daun rimbang memiliki nilai $\mathrm{LC}_{50}$ yang lebih tinggi daripada nilai $\mathrm{LC}_{50}$ ekstrak batang dan buah rimbang pada penelitian ini.

Silva et al. (2007) melaporkan bahwa ekstrak metanol bagian atas dari tanaman rimbang di daerah Timur Laut Brazil memiliki efek toksik terhadap larva udang dengan metode BSLT. Nilai LC $_{50}$ yang didapatkan adalah 295,2 ppm. Nilai tersebut lebih tinggi dibandingkan nilai $\mathrm{LC}_{50}$ yang didapatkan pada penelitian ini. Bahan uji tersebut (bagian atas tumbuhan terdiri dari batang, daun, buah, dan bunga) yang digunakan lebih bervariasi daripada bahan penelitian ini, daya toksik dari bahan uji tersebut lebih rendah dibandingkan dengan kedua ekstrak pada penelitian ini. Hal ini dapat disebabkan dari perbedaan habitat, nutrisi tanah, dan umur tumbuhan tersebut. Habitat, dan nutrisi tanah dapat mempengaruhi kandungan dari suatu metabolit pada tumbuhan tersebut (Lambers et al., 2008). Umur tumbuhan merupakan faktor yang dapat mempengaruhi komposisi, konsentrasi, dan bioaktivitas metabolit pada tumbuhan tersebut (Alfarabi et al., 2015).

Kematian larva udang pada penelitian ini disebabkan oleh kandungan senyawa yang terdapat pada ekstrak buah dan batang rimbang (Tabel 1). Buah rimbang mengandung isoflavonoid dan steroid glikosida. Kedua senyawa tersebut memiliki bioaktivitas antiviral (Arthan et al., 2002). Bagian lainnya seperti batang dan daun mengandung banyak steroid dan saponin (Yousaf et al., 2013). Berdasarkan uji fitokimia, buah dan batang rimbang mengandung alkaloid. Telah diketahui bahwa alkaloid memiliki efek toksik seperti kuinin, kuinidin, dan Chichonine serta memiliki bioaktivitas lainnya seperti anti malaria, antioksidan, dan antikanker (Gurung \& De, 2017). Saponin terdeteksi pada ekstrak batang rimbang dan tidak terdeteksi pada 
ekstrak buah rimbang. Senyawa tersebut merupakan golongan isoprenoid dan berfungsi sebagai toksin bagi hewan herbivora dan cendawan. Saponin secara umum banyak disintesis pada daun dan batang (Heldt, 2011), oleh karenanya hal ini menyebabkan tidak terdeteksinya saponin pada ekstrak buah. Tanin juga dideteksi terdapat pada ekstrak buah dan batang rimbang. Tanin memiliki efek toksik pada organisme lainnya dikarenakan dapat berikatan dengan protein (Heldt, 2011), sehingga senyawa tersebut dapat memiliki efek toksik dan bioaktivitas seperti antimikroba (Naz et al., 2017).

\section{SIMPULAN}

Ekstrak buah dan batang rimbang (Solanum torvum) pada penelitian ini memiliki efek toksik dengan nilai $\mathrm{LC}_{50}$ sebesar 248 ppm untuk ekstrak buah rimbang, dan nilai $\mathrm{LC}_{50}$ sebesar 129 ppm untuk ekstrak batang rimbang. Ekstrak buah rimbang mengandung senyawa alkaloid dan tanin, sedangkan hasil uji fitokimia terhadap batang rimbang mengandung alkaloid, saponin, dan tanin. Hal ini menunjukan bahwa kedua ekstrak tersebut memiliki potensi untuk dikembangkan menjadi salah satu sumber fitofarmaka antikanker.

\section{REFERENSI}

Ahmadinejad, F., Møller, S. G., Chaleshtori, M. H., Bidkhori G., \& Jami, M. S. (2017). Molecular mechanisms behind free radical scavengers function against oxidative stress. Antioxidants, 6(3), 1-15.

Alfarabi, M., Rosmalawati, S., Bintang, M., Miftahudin, Rofa'ani, E., \& Chaidir. (2015). Antiproliferationactivity of tuber protein Typhonium flagelliforme (Lodd.) blume on MCF-7 cell line. International Journal of Biosciences, 6(12), 52-60.

Alfarabi, M., \& Fauziayuningtias, A. (2017). Analisis nilai toksisitas ekstrak biji pepaya (Carica papaya) dengan metode Brine Shrimp Lethality Test (BSLT). Natural Science: Journal of Science and Technology, 6(2), 153-158.

Arthan, D., Svasti, J., Kittakoop, P., Pittayakhachonwut, D., Tanticharoen, M., \& Thebtaranonth, Y. (2002). Antiviral isoflavonoid sulfate and steroidal glycosides from the fruits of Solanum torvum. Phytochemistry, 59(4), 459-463.

Gurung, P., \& De, P. (2017). Spectrum of biological properties of cinchona alkaloids: a brief review. Journal of Pharmacognosy and Phytochemistry, 6(4), 162-166.

Harborne, J. B. (1987). Metode fitokimia: penuntun cara modern menganalisis tumbuhan edisi II. Diterjemahkan oleh Padmawinata K dan Sudiro I. Bandung: ITB Press.

Heldt, H. W. (2011). Plant biochemistry $4^{\text {th }}$ edition. Oxford: Elsevier.

Julfitriyani, Runtuwene, M. R., \& Wewengkang, D. (2016). Uji aktivitas antioksidan dan toksisitas ekstrak etanol daun foki sabarati (Solanum torvum). Jurnal Ilmiah Pharmacon, 5(3), 94-101.

Lambers, H., Chapin, F. S. III., \& Pons, T. L. (2008). Mineral nutrition. In H. Lambers, F. S. Chapin III, \& T. L. Pons (Eds), Plant physiological ecology $2^{\text {nd }}$ ed (pp 255-310). Cheddar, UK: Springer

Loganayaki, N., Siddhuraju, P., \& Manian, S. (2010). Antioxidant activity of two traditional indian vegetables: Solanum nigrum L. and Solanum torvum L. Food Science and Biotechnology, 19(1), 121127.

Meyer, B. N., Ferrigni, N. R., Putnam, J. E., Jacobsen, L. B., Nichols, D. E., \& McLaughlin, J. L. (1982). Brine shrimp: a convenient general bioassay for active plant constituents. Journal of Medicinal Plant Research, 45(5), 31-34.

Naz, R., Ayub, H., Nawaz, S., Islam, Z. U., Yasmin, T., et al. (2017). Antimicrobial activity, toxicity and anti-inflammatory potential of methanolic extracts of four ethnomedicinal plant species from Punjab, Pakistan. BMC Complementary and Alternative Medicine, 17(1), 1-13.

Silva, T. M. S., Nascimento, R. J. B., Batista, M. M., Agra, M. F., \& Camara, C. A. (2007). Brine shrimp bioassay of some species of Solanum from Northestern Brazil. Brazilian Journal of Pharmacognosy, 17(1), 35-38. 
Sirait, N. (2009). Terong cepoka (Solanum torvum) herba yang berkhasiat sebagai obat. Warta Penelitian dan Pengembangan Tanaman Industri, 15(3), 10-12.

Taiz, L., \& Zeiger, E. (2002). Plant physiology $3^{r d}$ edition. Oxford: Sinauer Associates.
Yousaf, Z., Wang, Y., \& Baydoun, E. (2013). Phytochemistry and pharmacological studies on Solanum torvum Swartz. Journal of Applied Pharmaceutical Science, 3(4), 152-160. 